\title{
Exploration of ways in Ideological and political education in University and Research on Entrepreneurship Education
}

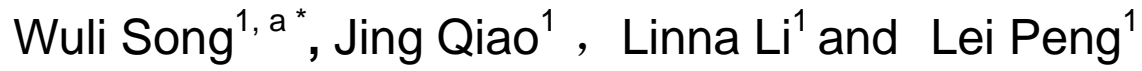 \\ ${ }^{1}$ College of Information Engineering, Taishan Medical University,Taian,Shandong 271016,China \\ a)Authors to whom correspongence should be addressed.Electronic addresses:songswl@163.com \\ * the corresponding author
}

Fund project: Colleges and universities in shandong province humanities and social science research project (J13SY69) and Tai'an City social sciences planning project (14SKX038)

\section{Keywords: Entrepreneurship Education;Ideological and Political Education;Effect;depend on}

\begin{abstract}
In this paper, the implementation of entrepreneurship education on college students analyze the significance, followed by demonstration on the relationship between Ideological and political education and entrepreneurship education. On the ideological and political education in college students analyze the factors restricting the development of entrepreneurship. Analysis on the main problems existing in the entrepreneurship education in Ideological and political education and the causes. Put forward the innovation and entrepreneurship education of Ideological and political education method, has carried on the analysis from six aspects, namely, to optimize the environment of entrepreneurship education, improve education level; optimization of entrepreneurship education form, reform education mode; shape students' entrepreneurial personality, stimulating the entrepreneurial consciousness; strengthening entrepreneurial education troop construction, to ensure the effectiveness of education; the importance of entrepreneurship education and practice method, cultivating entrepreneurial ability; system construction of entrepreneurship education, realize the education standard development.

All countries government and educational circles have entrepreneurship education as a quality education and practical education to operate. Play to the ideological and political education in college students' role of entrepreneurship education, is the essence of development, and the function of Ideological and political education practice requirements, is the ideological and political education training aim. We only better analyze their connotation and relationship can we grasp its contact. The ideological and political education is the society or social groups use certain ideas, political views, moral norms, influence has the goal, has the plan, has the organization to its members, so that they are consistent with the demands of the society moral social practice activities. [1] entrepreneurship education refers to the combination of professional education, business knowledge, training students' entrepreneurial competence and entrepreneurial quality, make the students after graduation bold to society, their own business and the self development education. Entrepreneurship education as a new education idea and education mode, it is proposed to adapt to the current social demand. Only the implementation of entrepreneurship education, in order to make the university graduates talent showing itself in the fierce talent competition, only to train university students to entrepreneurial talent, can really solve the problem of employment.
\end{abstract}




\section{It has important significance to implement entrepreneurship education of College Students}

With the need of the reform of education system and economic development, China's higher education from elite education to mass education gradually become traditional, this reform mode makes the college graduates increased year by year, the existing social work hard to meet the needs of the graduates, entrepreneurship has become an important way to solve the employment of graduates, it has become an important factor in my country economy health development and the construction of harmonious society. The economic and social transformation, the reform and development of higher education, University Students' all-round development needs of college students entrepreneurship education. Entrepreneurship education is the need of China's economic and social development, entrepreneurship education is the need of higher education reform and development, entrepreneurship education is to promote college students' all-round knowledge, management knowledge, legal knowledge, financial knowledge and marketing knowledge system. The development of entrepreneurship education, on the one hand is to impart knowledge, on the other hand, cultivating an important quality of college students, and further reflects the value of its own students to pay attention to the overall development, and contribute to the overall development of College students.

\section{Relationship between Ideological and political education and Entrepreneurship Education}

Through entrepreneurship education, quality cultivation of moral quality and the ability of entrepreneur, cultivate the basic quality of entrepreneurship is to cultivate entrepreneurial talent. Stimulating the entrepreneurial awareness, encouraging entrepreneurship emotion, entrepreneurial ability raise and entrepreneurial personality, all cannot do without the people's world outlook, the outlook on life, values "three views" culture, so we must strengthen the ideological and political education.

Is the difference between the two, their educational objectives and content of different, different service object. Entrepreneurship education as the research object to the law of enterprise education, to improve the education of entrepreneurship and entrepreneurial quality as the goal. [2] the connection of the two, one is similar to the education goal. The quality of entrepreneurship in the sense of entrepreneurship, entrepreneurship and entrepreneurial quality and ideological and political education goal has a natural connection, and like the College Ideological and political education, entrepreneurship education under the condition of socialism to develop the education object's innovative consciousness, innovative thinking and innovative ability, cultivate independence, dare, tenacity, restraint and cooperation and other personal qualities, cultivating innovative, create, entrepreneurial talent as a fundamental goal, this is also the value of the new era content. Two is the similarities in the content of education. Entrepreneurship education to the education of ideal and faith education, mental health education, carve, solidarity to foster collaboration consciousness of the content of education, so as to stimulate the entrepreneurial motivation, shaping the quality of entrepreneurship. Three is the common way in education. Besides the theory of indoctrination, two people are constantly exploring the characteristics of the times with the education mode and the carrier, strengthen the pertinence and actual effect of education; pay attention to theory of education, develop the organic combination of education, practice education. 


\section{Analysis of the causes of the ideological and political education in Entrepreneurship Education Problems}

Entrepreneurship Education in Ideological and political education on the inadequate attention, entrepreneurship education in the theoretical research on Ideological and political education is relatively weak, the ideological and political education in entrepreneurship education curriculum system has not yet formed, [3] entrepreneurship education is the practice of education, teaching material system should be further perfected. Teachers to write more scientific and reasonable in view of business simulation and case teaching. Holding the business knowledge forum, invite the business elite lectures, students participate in science and technology innovation competition and practice course is we want to discuss the issue.

\section{Innovation and entrepreneurship education method of Ideological and Political Education}

Optimization of entrepreneurship education environment, improving education level. The deepening of campus culture, improve the level of Ideological and political education. Western countries said culture influence for the "hidden curriculum", is a high level of influence character by environment education, is essential in the process of forming students' ideology and morality, its role is not less than the formal curriculum. Ideological and political education by the enterprising spirit of publicity and promotion, and actively play the cultural function of education environment. Entrepreneurship education can adopt the combining point and way of education, pay attention to create a business atmosphere is an important aspect of. Good environment can make people more easily accept the entrepreneurial education content, can promote the smooth implementation of entrepreneurship education, so the optimization of Ideological and political education environment of college students entrepreneurship education plays an important role.

Optimization of entrepreneurship education form, reform education mode. Entrepreneurship education implementation through classroom teaching, lectures, business and other forms of influence character by environment simulation. Through combining with professional education, combined with social practice, combined with the college students' scientific research, can better stimulate and encourage students to entrepreneurial passion, to foster the students' creative ability. Career education in students ideological and political education, as an important part of the students' comprehensive quality, to train students' ability in the correct analysis and understanding of realistic problems, reform the traditional teaching mode, the new mode of Ideological and political teaching construct view interaction, case analysis and divergent thinking.

Shaping the students' entrepreneurial personality, stimulating the entrepreneurial consciousness. To actively play the role of Ideological and political education, strengthen entrepreneurship education propaganda, set up the business model, is more easily accepted in college students entrepreneurial cognition and emotion, to improve college students' entrepreneurial interests, establish strong entrepreneurial beliefs and entrepreneurship values, the formation of stable drive, stimulating the entrepreneurial consciousness.

Strengthen entrepreneurship education troop construction, to ensure the effectiveness of Education.We should properly handle the relationship between education and education, emphasis on entrepreneurship education of middle school students the main role to play, is not equal to ignore, weakening the role of the teacher subject of entrepreneurship education, to correctly handle the relationship between the two. Entrepreneurship education teachers are the key to develop 
entrepreneurship education, students receive knowledge, entrepreneurial ability influence teachers' teaching skills. This requires a mastering business knowledge, rich social practice part-time personnel to be competent, through entrepreneurship education system of training students pioneering the concept of entrepreneurship, entrepreneurship theory and practice.

At present our country colleges and universities engaged in entrepreneurship education is ideological and political teachers students, weak research on entrepreneurial theory, rarely have the entrepreneurial capabilities and entrepreneurial experience, confuse the entrepreneurship education and employment education, not separated. One is to optimize business faculty, hired a number of successful entrepreneurs as part-time teachers give students courses, hire some practical experience of the technical experts to teach experience, the formation of part-time teachers, reasonable collocation of teachers. Two is the establishment of teaching and research base, let the teachers in-depth high-tech enterprises, production, learning and research integration "of the road, let teachers feel entrepreneurial experience, familiar with enterprise operational procedures, save poineering case, enhance the teaching experience. Three is to enhance the quality of the students in the ideological and political workers, through training, testing and other means, the students ideological and political workers training into the backbone of entrepreneurship education.

The importance of entrepreneurship education and practice method, innovative ability. Practice is the sole criterion for truth, practice education is an important index system, test the feasibility through the practice of entrepreneurship, entrepreneurs can get rich social resources, make students realize the perfect combination of profession and occupation, to improve college students' social living ability and entrepreneurship ability. [4] entrepreneurship education and practice is to improve the action ability and the ability to execute the entrepreneurship of college students, and professional and technical ability, comprehensive performance management ability and comprehensive ability.

The establishment of university students entrepreneurial base, build entrepreneurial platform, guide the students to actively undertaking.Make full use of the resources, reduce the risk of College Students Entrepreneurship.Based on the students' science and technology innovation, cultivating innovative ability.The integration of cyber source, service of entrepreneurship education.

The system construction of entrepreneurship education, realize the education standard development. The construction of entrepreneurship education system. "Opinions" pointed out that the Ministry of education on vigorously promoting higher education and college students start their own businesses in: "universities to innovation and entrepreneurship education and school students independent venture work into the important agenda. To straighten out the leadership system, the establishment of a sound scientific research, teaching, employment and Youth League Committee, University Science and Technology Park and other departments to participate in the innovation and entrepreneurship education and entrepreneurial work coordination mechanism. Base planning innovation and entrepreneurship education, entrepreneurship, entrepreneurial venture construction of policy support and guidance service work, a clear division of labor, increase input in personnel, venues, funding, the formation of long-term mechanism." [[]] entrepreneurship education campus culture is a system engineering, we must establish a set of comprehensive rules and regulations system. 


\section{Conclusion}

To sum up, the positive enterprising spirit, excellent entrepreneurial quality and comprehensive ability of entrepreneurship, through both inside and outside the school entrepreneurship practice base, the best for the students to provide funds, location and policy has practical significance and guidance needs and interests of their own actual, entrepreneurship education is the connotation and extension of system of College Students' Ideological and political education. Symbiotic and fusion, and very distinctive characteristics of the times, the ideological and political education of entrepreneurship education has pertinence and effectiveness based on, is effective to promote. How to give full play to the ideological and political education research is of great practical significance and theoretical significance in the role of entrepreneurship education for college students.

\section{References}

[1]Lijun Liu.Talking about the innovation of Ideological and political education of College Students[J].Journal of Dalian Education College, 2005, (1).

[2]Qinya Jiang: A new perspective of entrepreneurship education, ideological and political education in Colleges and Universities , Journal of Nanjing Institute of Technology (SOCIAL SCIENCE EDITION) , 2007,12.

[3]Wenzhong Cheng.Entrepreneurship education for College Students[J].Journal of Fuzhou University: Philosophy and Social Sciences Editio,2009(2):94-97.

[4]Guiren Yuan: 《Focused firmly implement the go to all lengths do a good job in the employment of college graduates in 2011 http://www.moe.edu.cn/publicfiles/business/htmlfiles/moe/moe_176/201011/111982.html

[5]Ruifeng Lu.Analysis of the influence of campus culture on College Students' Entrepreneurship[J].China Adult Education,2008,(8).

[6] 《CPC Central Committee and State Council on Further Strengthening and improving ideological and political education of College Students $》$, http://www.ccmusic.edu.cn/zzjg/dwbm/xcb/llyd/200802/t20080226_3369.html

[7]Yuhui Ge: The assessment of College Students' Entrepreneurship, Tsinghua University press , Version 2010 page 169th.

[8]Ministry of Education Ministry of Education: opinions on vigorously promoting higher education and college students' independent pioneering work , http://www.jyb.cn/info/jyzck/201005/t20100514_359988_1.html

[9]The CPC Central Committee and State Council: on Further Strengthening and improving ideological and political education of college students views,http://www.gxut.edu.cn/xbsz/shkxx/shownews.asp?id=349\&sortid=20\&Page=1 。

[10]Yan Li、Xiaohui Yang: Cultural Consciousness: the rational logic of Ideological and political education in Universities[J], China higher education,2013,2 .

[11]Changsong Li: Under the background of internationalization of university students ideological characteristics and variation of $[\mathrm{J}]$, The school party building and Ideological Education,2013,(1). 